\title{
COMMERCIAL RELATIONS OF THE UNITED STATES WITH CANADA
}

\author{
By John Ball Osborne,
}

Chief, Bureau of Trade Relations, Department of State, Washington, D. C.

Nature is a most powerful ally in the development of the commercial relations between the United States and the Dominion of Canada. That great northland, with an area exceeding that of this country and with a population of six million energetic, ambitious souls, has enormous natural resources and is rightly spoken of by its statesmen and economists as a land of "almost infinite possibilities." With Canada the United States has many mutual interests and there is a marked homogeneity in the people of the two countries. A glance at the map must inevitably suggest that political arrangements frequently fail to follow rational commercial lines. A straight line connecting the northern boundaries of Minnesota and Maine will cut from the Dominion the richest and most populous portions of Ontario and Quebec, and, as a matter of fact, the commercial interests of the provinces along the Anerican border are quite as intimately connected with those of the adjoining states as with each other. Thus, the maritime provinces are geographically related to New England; Ontario to New York, Pennsylvania, Ohio, and Michigan; Manitoba and the Northwest territories to Minnesota, North Dakota, and Montana; and British Columbia to our Pacific Coast states.

Under these favoring national conditions it might be expected that there would be the freest commercial intercourse between the two countries, the principal limitation being the law of supply and demand as regards American imports of Canadian natural products and the consuming ability of the Canadian people as regards the diversified exports of the United States. In a measure this is true. The commercial movement between the two countries is indeed extensive, as the statistics given below show; but it is not as intimate and important as it would be were it not for the operation of two great factors-colonial sentiment and tariff barriers. Sentiment alone figures very little in the determination of international 
commerce; but in this case it was the colonial tie that inspired and created the preferential tariff system of Canada, and this is a factor that cannot be ignored.

In recent years the Dominion of Canada has come into the ranks of the commercial countries of the world. Its total trade in $\mathrm{I} 883$ was $\$ 230,000,000$; in 1893 , it had risen to $\$ 248,000,000$; in I903, to $\$ 467,000,000$, and in 1906 it exceeded $\$ 550,000,000$.

The trade between the United States and Canada in each year since 1903 was as follows :

\begin{tabular}{|c|c|c|}
\hline Fiscal Year (United States). & $\begin{array}{l}\text { Imports into the United } \\
\text { States from Canada. }\end{array}$ & $\begin{array}{l}\text { Exports to Canada from } \\
\text { the United States. }\end{array}$ \\
\hline 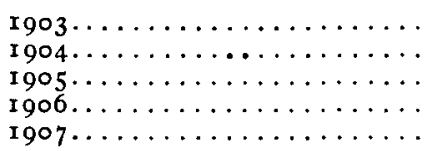 & $\begin{array}{r}\$ 54,781,418 \\
51,552,791 \\
62,469,632 \\
68,237,653 \\
73,334,615\end{array}$ & $\begin{array}{r}\text { \$ } \text { I }_{2} 3,266,788 \\
\text { I } 31,234,985 \\
\text { I } 40,529,581 \\
\text { I } 56,736,685 \\
\text { I } 83,206,067\end{array}$ \\
\hline
\end{tabular}

The importance of our trade with Canada is shown by the fact that in the fiscal year 1907 the value of the exports of American products to Canada was exceeded only by our exports to two countries, namely, the United Kingdom and Germany. Similarly in the same year our imports from Canada were exceeded in value by the imports from only five countries, namely, the United Kingdom, Germany, France, Cuba, and Brazil.

As might be expected, nearly everything that Canada sends to this country falls within the description of raw materials for manufactures or foodstuffs. The principal items making up our imports from Canada in I907 were logs, lumber, and wood pulp; copper and nickel ores; hides, skins, and furs; fish and animals; and bituminous coal. These in fact, have been the classes of articles that have been most largely imported ever since the days of the reciprocity treaty.

As regards American exports to Canada, while there are many heavy items coming in the category of raw materials, such as coal, both anthracite and bituminous; raw cotton, cereals, leaf tobacco, fruits, etc., the bulk of the exportation represents manufactured articles, particularly iron and steel goods, agricultural implements, chemicals, railway material, carriages, paper, etc.

The interchange of the same articles of merchandise has always 
been a noteworthy phenomenon in our trade with Canada. Thus, one article may be exclusively an import in one state along the border and an export in another, or its status may be determined by the condition of the crops. The principal articles which figure both as imports and exports are the following: animals, breadstuffs, copper, fish, fruits, hides and skins, and vegetables. There is considerable border traffic in vegetables in both directions, particularly in the northeast. The identity of some of these elements in the trade has more than once been advanced as an argument against reciprocity. Thus, when the Senate was considering, in 1865 , the termination of the Marcy-Elgin treaty, Senator Conness, of California, exclaimed:

How you can make a treaty reciprocal between two countries lying contiguous to each other which have the same products, the same class of industries, I cannot exactly see. Subject the arrangement of that reciprocity to a treaty, or the mode furnished by a treaty, and you have simply an arrangement in which each party endeavors to cheat the other in making the agreement to be arrived at.

The following table, from official Canadian statistics, ${ }^{1}$ gives the total exports from Canada in specified years from I868 to I906, and the shares going to the United Kingdom and the United States respectively:

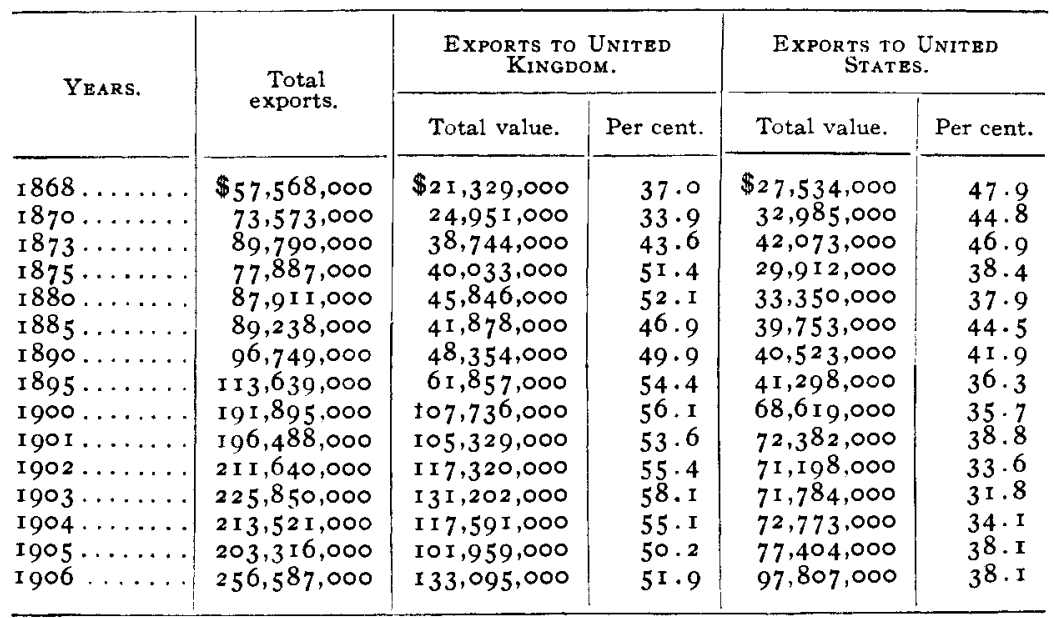

${ }^{1}$ From Tables of the Trade and Navigation of the Dominion of Canada. 
It appears from the foregoing table that the mother country is the best customer of Canada and the United States the next best, the percentages in 1906 being respectively fifty-two and thirty-eight. The table indicates, too, that not since the early seventies has the United States been as extensive a purchaser of Canadian goods as the United Kingdom. This, perhaps, will be a surprise to many persons who have supposed that this country constitutes Canada's largest market.

It is more interesting and significant, however, to consider the imports for consumption into Canada for the same years as above given, with special reference to the United States and the United Kingdom. These figures are given in the following table from Canadian sources: ${ }^{2}$

\begin{tabular}{|c|c|c|c|c|c|}
\hline \multirow{2}{*}{ Years. } & \multirow{2}{*}{$\begin{array}{c}\text { Tutal imports } \\
\text { for consumption. }\end{array}$} & \multicolumn{2}{|c|}{$\begin{array}{l}\text { IMPORTS FOR CONSUMPTION } \\
\text { FROM UNITED KINGDOM. }\end{array}$} & \multicolumn{2}{|c|}{$\begin{array}{l}\text { IMPORTS POR CONSUMPTION } \\
\text { FROM UNITED STATES. }\end{array}$} \\
\hline & & Total value. & Per cent. & Total value. & Per cent. \\
\hline I 868 & $\$ 71,985,000$ & $\$ 36,664,000$ & 50.9 & $\$ 26,315,000$ & 36.6 \\
\hline 1870 & $71,238,000$ & $38,595,000$ & 54.2 & $24,728,000$ & $34 \cdot 7$ \\
\hline 1873 & I 27,5 I 5,000 & $68,5^{2} 3,000$ & $53 \cdot 7$ & $47,736,000$ & $37 \cdot 4$ \\
\hline 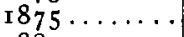 & I I 9,6 I 9,000 & $60,347,000$ & 50.5 & $50,806,000$ & $42 \cdot 5$ \\
\hline 188 & $71,782,000$ & $34,46 \mathrm{I}, 000$ & 48.0 & $29,347,000$ & 40.9 \\
\hline 188 & $102,710,000$ & $41,407,000$ & 40.3 & 47, I 5 I,000 & 45.9 \\
\hline 189 & I I $2,766,000$ & $43,390,000$ & 38.5 & $52,292,000$ & 46.4 \\
\hline I895 & $105,253,000$ & $3 x, 132,000$ & 29.6 & $54,635,000$ & 51.9 \\
\hline I897 & I I I $, 294,000$ & 29,4 I 2,000 & $26 . \mathrm{I}$ & $61,649,000$ & 55.9 \\
\hline 1900. & I $80,804,000$ & $44,790,000$ & $24 \cdot 7$ & $109,844,000$ & 60.7 \\
\hline I9OI. & $181,238,000$ & $43,018,000$ & $23 \cdot 7$ & I I $0,485,000$ & 60.9 \\
\hline 1902 & $202,792,000$ & $49,206,000$ & $24 \cdot 3$ & I 20,8 I 5,000 & 59.6 \\
\hline 1903. & $233,791,000$ & $5^{8,897,000}$ & $25 \cdot 2$ & I $37,6 \circ 5,000$ & 58.9 \\
\hline rgo & $251,464,000$ & $61,778,000$ & 24.6 & I $50,827,000$ & 60.1 \\
\hline 1905 & $261,926,000$ & $60,343,000$ & 23.0 & $162,739,000$ & 62.1 \\
\hline 1906 & $290,361,000$ & $69,195,000$ & $23 \cdot 8$ & I $75,862,000$ & 60.6 \\
\hline
\end{tabular}

Here we see that the conditions are precisely reversed in comparison with the statistics of exports from Canada, for the share of the imports from the United Kingdom has steadily declined from 50.9 per cent of the total in 1868 to 23.8 per cent in 1906 , while the share of the imports from the United States has increased from 36.6 per cent to 60.6 per cent. These results are remarkable when it is remembered that the relative loss of the mother country and corresponding gain of the United States have been apparently in

2 From Tables of the Trade and Navigation of the Dominion of Canada. 
defiance of the preferential tariff treatment enjoyed since 1897 , in varying degrees, by numerous classes of British products at the expense of the like products of American origin. The inference drawn by many persons from this state of affairs is that the proBritish tariff of Canada has been ineffectual. I am not prepared to accept this conclusion, but am strongly of the belief that the preferentials in favor of the goods of the mother country have actually exerted, especially since I90o, an important, although indeterminable, influence. In other words, I am of opinion that since British manufactures enjoyed a rebate of one-third the regular duties, the Canadian tariff has exerted a restrictive effect upon the normal growth of American export trade to that country, so that our share might have been in 1906 perhaps 75 per cent, instead of $6 \mathrm{I}$ per cent, if the trade of the United States had not suffered this differential treatment in competition with British industries.

But be this as it may, the table shows that Canada makes the bulk of her foreign purchases in the American market, notwithstanding the preferentials and the colonial or imperial sentiment. Commenting upon this state of affairs, the editor of the London Financial Times recently remarked that what has evidently been accomplished by the preferential tariff is a checking of the decline in British exports to Canada which set in between the years 1892 and $I 895$, and in this respect, he thought, it has performed a service to British manufacturers. While this is undoubtedly true, some share of the credit for arresting the decline mentioned is due to British exporters who have awakened in recent years to the necessity of energetic efforts in order to maintain their hold on the Canadian market. I quote the following extract from the editorial refersed to:

The geographical position of Canada, it is obvious, is a severe handicap to British manufacturers and a corresponding advantage to United States merchants. There is also what, perhaps, is too often overlooked here-the immense advantage given to the states by the approximation of social and economic conditions in the two countries. To so great an extent is this the fact that the manufacturers of the states can regard the Dominion as being in many of its requirements merely an extension of the home market and as not needing specialized lines or methods of production such as our manufacturers would in many cases have to undertake before they could hope to compete on equal terms. The big point in our own favor consists in the fact that we are Canada's principal customer, with the result that there is always 
a large tonnage moving eastward and providing comparatively low freights for return business. Then we have the preferential tariff and that wider preference in good will which arises from our political connection and our ties of blood.

While the preferential tariff is a most important factor in building up trade between the Dominion and the United Kingdom, it is not difficult to account for the steady increase of imports from the United States. All our consular officers stationed in Canada agree that American goods are held in high favor as respects quality. In a recent report Consul Van Sant, of Kingston, says that in the long run, notwithstanding the keenest competition and sentiment, the natural advantages in geographical position and common commercial interests and tastes seem to count favorably, and the importation of manufactures from the United States continues to lead. In order to hold this position, he cautions the American exporter to watch the situation and to meet every new wave of industrial competition by extending fair trade inducements to Canadian merchants who buy abroad. Consul Van Sant also makes the gratifying announcement that there are no complaints against American packing methods in his district, and that the usually admitted superiority of American goods and their quick transit across the border, along with the low average of breakage and damage, have aided largely in bringing about the leading trade position enjoyed by the United States. It would seem that these considerations explain the apparent failure of the preferential tariff to accomplish what its framers claimed for it.

In several important lines of manufactured goods the United States enjoys in the Canadian market an apparently securely entrenched position notwithstanding differential tariff treatment in competition with the industries of the mother country. It may be of interest to note a few of these industries in which the United States is strongest and the United Kingdom weakest. Such are agricultural implements and machines, tools and hand or machine implements, portable machines and parts, locomotives, railway cars, copper manufactures, electrical apparatus, and iron and steel manufactures. In some of these classes of Canadian imports the share of the United States is as high as 90 or 95 per cent, thus giving a virtual monopoly. This position is likely to be maintained indefinitely, excepting in so far as modified by the growth of domestic 
manufactures, including the Canadianized American plants, to which I shall presently refer.

On the other hand, the classes of manufactures in which our British rivals have been aided materially by the preferentials include the miscellaneous metal trades, hardware, cutlery, jewelry, etc. ; textiles; waterproof clothing; leather goods; steam engines and boilers; some kinds of iron and steel, particularly pig iron; and earthenware. In all these lines the gain of Great Britain seems to have been at the expense of the United States. Still other British industries that have been benefited by the preference are hats, caps, and bonnets; drugs, dyes, and chemicals; china and porcelain; and cement, although in these classes the trade of the United States has kept pace with the increase in the Canadian demand and has generally increased more rapidly. At any rate, the classes of manufactured goods that $I$ have enumerated in this paragraph are those in respect of which we have good cause to apprehend increasingly keen competition from the mother country as a direct result of the heavy tariff preference.

The following interesting tables, showing the general course of Canadian trade from 1884 to I 905 , were compiled by the Canadian Tariff Commission in 1907. While some of the percentages are slightly different from those I have given above, the discrepancies are due simply to taking total imports in one case and total imports of merchandise for consumption in the other:

Table A.-Imports into Canada: Percentage Derived from Different Sources.

Origin. $\quad$ 1884. $1894 . \quad$ 1904. 1905.

United Kingdom ................... 40.I $34.2 \quad 24.6 \quad 23.6$

The rest of the empire.............. 3.I $\quad 2.5 \quad 4.4 \quad 5.1$

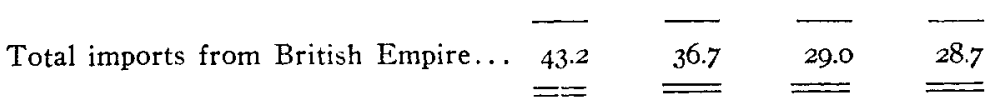

United States

$\begin{array}{llll}46.7 & 46.9 & 60.0 & 60.7\end{array}$

Other foreign countries..............

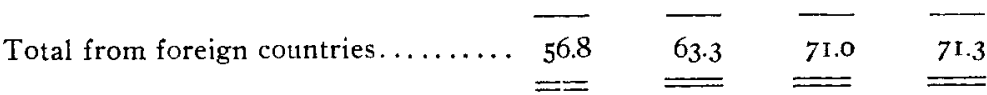

According to the above table the imports into Canada from the mother country fell from 40.1 per cent in 1884 to 23.6 per cent in (336) 
I905, while those from the United States rose from 46.7 per cent to 60.7 per cent in the same period.

Table B.-Exports from Canada: Percentage to Various Destinations.

Destination. $\quad$ I884. I894. $\quad$ I904. $\quad$ I905.

United Kingdom ................... $46.9 \quad 58.5 \quad 55.4 \quad 50.6$

$\begin{array}{llllll}\text { The rest of the empire................. } 4.8 & 4.0 & 5.7 & 5.9\end{array}$

Total exports to British Empire..... $\stackrel{5 \mathrm{II} .7}{=} \stackrel{63.5}{=} \stackrel{6 \mathrm{I.I}}{=}$

United States $\ldots \ldots \ldots \ldots \ldots \ldots \ldots \ldots, 43.0$

\begin{tabular}{rrrr}
31.6 & 33.7 & 37.4 \\
4.9 & 5.2 & 6.1 \\
\hline 36.5 & 38.9 & 43.5 \\
$\underline{=}$ & $\underline{=}$
\end{tabular}

Total to foreign countries.......... $48.3 \quad \stackrel{36.5}{=} \stackrel{38.9}{=}$

It appears from the foregoing table that the exports from Canada to the mother country rose from 46.9 per cent in 1884 to 50.6 per cent in 1905, while, in the same period, those to the United States declined from 43 per cent to 37.4 per cent. It should be borne in mind, of course, that this is simply a statement of respective shares expressed in percentages, for Canadian exports to the United States have, as we have seen, increased to a formidable figure. What the table does show, however, is that the mother country was buying more, relatively, and the United States less, relatively, in 1905 than in 1884 in the Canadian market. On the principle of natural reciprocity in trade-that a nation should buy where it would sell- the percentages of the Tariff Commission seem to me to point a certain moral and to be pregnant with meaning, the trend of the second table (B) foreshadowing a different story for the first table (A), when they shall be recast a few years hence.

The statistics that I have presented show, I think conclusively, that the pro-British tariff has failed to accomplish the divergence in international trade which its founders and advocates anticipated; but it would be unwise to minimize its importance, for the time may come when tariff differentials against American goods of $33^{1 / 3}$ per cent, or even 25 per cent, will suffice to ruin our export trade to the Dominion. There is no partisanship in the proposition that the continuance of our industrial prosperity is essential to the continuance and progress of our foreign trade. If the present halcyon period were to be succeeded by one of depression and stagnation, 
all experience indicates that foreign tariff restrictions against American products that are now, on the impulse of the waves of prosperity, overridden without much difficulty, would become stone-wall obstacles. It therefore should be a matter of general concern to understand precisely the character of the Canadian tariff system.

Prior to I897 Canada, like the majority of countries and colonies, employed the single tariff system. In that year the Parliament of the Dominion adopted a double tariff, consisting of the regular tariff and the preferential tariff in favor of the mother country and reciprocating colonies. During the first year the reduction allowed as preference was only $121 / 2$ per cent; but by the terms of the original law (May 13, I897) this was increased in 1898 to 25 per cent. It remained at that figure until July I, I900, when, by an order previously made in council, it was increased to $33^{1} / 3$ per cent, and this continued to be the uniform reduction in duties on imports from the United Kingdom and reciprocating colonies (mostly in the West Indies) until the triple tariff of 1907 went into effect. While the Canadian tariff during the period 1897 to 1907 was virtually a double tariff, like the maximum and minimum tariff of France, it was a single tariff in form, with a single schedule of duties applicable to all foreign countries alike, the provision for preferential treatment within the British. Empire being a separate feature of the law.

The apparent ineffectiveness of the British preferentials was the principal reason for the revision of the tariff in 1907 on an entirely new plan, which bids fair to have far-reaching results. In preparation for the revision a tariff commission collected a mass of evidence in 1906 in the different industrial centers, both in the Dominion and in England, as regards the effect of the then existing uniform preference of $33^{1} / 3$ per cent and the needs and wishes of the business interests concerned. As adopted by the Canadian Parliament, the new tariff consists of three schedules of duties on the same articles published in parallel columns, thus making the system a unique triple tariff. These columns are headed respectively "British Preferential Tariff," "Intermediate Tariff," and "General Tariff."

The rates of the "General Tariff," applicable to the United States, are not radically different from those of the old tariff. The average ad valorem rate of duty collected in 1906 on total dutiable imports from the United States was 24.8 per cent, and on total 
free and dutiable imports I3.I per cent, thus showing a moderate tariff of the protective class.

Considerable change was made in the British preferential tariff. Instead of the former flat rebate of $33^{1 / 3}$ per cent, fixed duties, mostly specific, were provided, some representing a higher preference than one-third and others a less. The preference was increased, speaking generally, on iron and steel and their manufactures, glass and glassware, earthenware and china, silk manufactures, and paper manufactures. It was made lower on cotton manufactures, woolen goods ; flax, hemp, and jute manufactures; drugs, dyes, and chemicals, and leather and its manufactures. It was estimated by the tariff commission that of the total dutiable imports (measured by valuation) from the mother country the preference was increased on 28 per cent and diminished on 72 per cent. It is also to be remembered that the preference will be materially diminished to the extent that the intermediate tariff shall be put into effect. It will presently be affected by the new Franco-Canadian reciprocity treaty.

The most interesting feature of the new law to the United States, however, is the intermediate tariff, standing in a column between the British preferentials and the general tariff, with rates for the most part from $2 \frac{1}{2}$ to 5 per cent lower than the general rates. This tariff is to be brought into operation by Canadian order in council after' negotiation with foreign countries which "give Canada favorable conditions," or with British colonies other than the reciprocating colonies which enjoy the preferentials.

Mr. Fielding, in outlining the intermediate tariff, made the following significant statement in Parliament:

All we do then by adopting this intermediate tariff is to hold it up to countries abroad and say: This is something which you may obtain if you desire by entering into negotiations with Canada; you may obtain the whole tariff for equal compensation or you may obtain a part of that tariff for compensation. You may obtain it from day to day by reciprocal legislation, or you may obtain it by a treaty brought about through the diplomatic channels. We do not therefore bring this middle tariff into operation at once, but we put it before the world as a statement of the terms and conditions upon which we are willing to negotiate with other countries, and in order that we may induce them to give us better terms and take from us a larger share of the products of Canada.

It has been the general impression that the intermediate tariff is an invitation extended mainly to the United States. France, how- 
ever, has been the first country to profit by it. A reciprocity convention between Canada and France was signed at Paris on September I9, 1907, whereby Canada granted to France the benefits of the intermediate tariff on a long list of French products, including practically everything in which that country is interested, and in return, France conceded to Canada her minimum tariff duties on a large number of Canadian products. This treaty has been approved by the Canadian Parliament and is now awaiting ratification by the French Senate, having been already approved by the French Chamber of Deputies. When it goes into effect in Canada it is obvious that it will have a double infuence, namely, it will impair pro tanto the value of the British preference on competitive goods and it will increase the differentiation against the United States until the latter shall obtain the same treatment.

Inasmuch as the United States cannot hope to obtain the benefit of the preferential tariff, which, of course, is restricted to the mother country and reciprocating colonies, all our interest centers in the possibilities of the intermediate tariff. By the provisions of the reciprocity convention above mentioned, France secures the rates of the intermediate tariff on no less than ninety-seven articles or classes of articles, almost exclusively manufactured goods. Here are some of them: canned meats; florist stock and trees; canned corn; canned fruit; all kinds of nuts; canned fish; confectionery; photographs, paintings and drawings; toilet preparations; printing and writing ink; tableware of china, porcelain, white granite or ironstone; cement; window glass; glassware in general; manufactures of lead, copper, brass, aluminum, gold, and silver, not otherwise provided for; clocks and watches and their movements; locomotives and motor cars; automobiles and motor vehicles; manufactures of iron, steel, or wood, n. o. p.; house and office furniture; dress goods, cotton threads; carpets and rugs of cocoa, straw, hemp, or jute; braids, fringes; handkerchiefs and corsets; velveteens and plush fabrics; musical instruments and talking machines; leathers; boots and shoes; trunks and valises; toys; gloves and brushes.

The treaty also contains a schedule of twelve classes of French goods enjoying the benefit of special duties. These include wines, books, drugs and medicines, laces and embroideries, silks, ribbons, and velvets.

But there are many other articles in the intermediate tariff not (340) 
provided for in the French treaty and yet possessing no little importance to our own trade, for the tariff consists of 7II numbers, including goods that are free in all three columns. For example, the item of typewriters does not occur in the French treaty, and yet the United States is interested therein. The duties are: preferential, $17 \% / 2$ per cent ad valorem; intermediate, $22 \mathrm{I} / 2$ per cent, and general, 25 per cent. It is the same with cornmeal; printing presses; agricultural machinery; stoves; wagons and carriages; bicycles and tricycles; and many other products of American ingenuity and skill. France has not obtained the reduced duties upon them because she is not concerned in their exportation to Canada; but the case is different when the trade relations between the United States and Canada are considered.

In this connection we are hardly concerned, except incidentally, with the equally serious question to the United States presented by the increased differentiation against American exports in the French market as a result of the Franco-Canadian treaty. Speaking of the concession by France to Canada of the minimum duties on agricultural machinery, Consul General Mason, of Paris, says in a recent report:

The difference between maximum and minimum French duties on agricultural machinery figures out, as has been stated in a previous report, to $\$ 3.86$ on a mower, $\$ 4.82$ on a reaper, $\$ 8.20$ on a binder, and $\$ 1.93$ on a hayrake. This disparity of import duties is sufficient, in addition to the high cost of steel, wood, and labor in the United States, to put the importers in France of American harvesting machinery at a disadvantage that will imperil their present splendid trade as soon as Germany, Great Britain, and henceforth Canada, can develop their production so as to cover the French market. Already the Canadian manufacturers are preparing to improve the larger opportunity that will be offered here, and it is reported that a harvesting machinery plant in Canada, which belongs to the American syndicate, will be enlarged and worked to its highest capacity for the export trade to France. The pending situation, if indefinitely prolonged, may result in transferring largely to Canadian territory this and several other industries which have been built up and have their native home in the United States.

To this testimony it is pertinent to add that of Consul General Bradley, of Montreal, who reports that a special commissioner, sent over by the British Board of Trade to find means of extending the trade with England, states that 122 of the leading manufacturing firms of the United States have operating branches in Canada, and declares that in Montreal alone $\$ 25,000,000$ to $\$ 75,000,000$ American 
capital is invested. The complicating effect upon our trade relations of an "American invasion" of this kind needs no comment.

When discussing the question of our commercial relations with Canada, one instinctively thinks of reciprocal tariff arrangements. In carrying out the policy of commercial reciprocity the object of the United States has always been to protect its export interests in foreign markets, granting no more in return for the concessions thus secured than is consistent with the principle of adequate protection of domestic industries. No more appropriate field for the inauguration of this policy could be suggested than the Dominion of Canada, for reasons which I mentioned at the beginning of this article. These considerations, indeed, actuated the two governments in concluding the Marcy-Elgin treaty of 1854, which went into effect in 1855 and remained operative until March 17,1866 , when it was terminated in consequence of notice on the part of the United States in accordance with congressional direction. That treaty established a certain measure of free trade between the contracting parties, inasmuch as it exempted from duties some twenty-eight classes of natural products when imported into either country from the other. The action of Congress in directing the termination of the treaty was quite generally approved by the people of the United States, although the mercantile interests engaged in the Canadian trade were, as a rule, in favor of its extension or at least renewal in revised form.

Repeated efforts to secure another reciprocity arrangement for the regulation of our commercial relations with Canada have been made, without result, since 1866 , notably in $1869,1874,1892$, and I898-99. The overtures came, I believe in each instance, from Canada. The Joint High Commission of I898-99 had made substantial progress toward an agreement on the subject of commercial reciprocity, which was only one of a dozen topics under consideration, when the sessions came to an abrupt termination as the result of a disagreement respecting the settlement of the Alaskan boundary dispute. There is every reason to believe that a satisfactory treaty of reciprocity could have been arranged had the Canadian commissioners been willing to conclude independently of the Alaskan boundary. The responsibility, therefore, for the absence of a reciprocity arrangement between the two countries does not, in my opinion, rest with the United States. 